\title{
PENGEMBANGAN MEDIA PEMBELAJARAN BERBASIS GENERIC GREEN SKILL IN PROJECT BASED LEARNING PADA MENGGAMBAR TEKNIK BERBANTUAN CAD
}

\author{
Keysar Panjaitan, Abdul Hasan Saragih, Saut Purba \\ PendidikanTeknik Mesin, Fakultas Teknik, Universitas Negeri Medan \\ 'pkeysar9@gmail.com; 2abdulhasan@unimed.ac.id; ${ }^{3}$ purbasaut@yahoo.com
}

\begin{abstract}
Abstrak: Penelitian ini bertujuan: (1) menghasilkan media pembelajaran generic green skill based learning pada project based learning pada mata kuliah menggambar teknik berbantuan CAD, (2) Mengetahui keefektifan media pembelajaran generic green skill based learning pada project based learning pada mata kuliah menggambar teknik berbantuan CAD. Penelitian ini menggunakan metode Research and Development yang diusulkan dengan model Borg \& Gall. Subjek penelitian adalah mahasiswa Jurusan Pendidikan Teknik Mesin Universitas Negeri Medan yang ditinjau oleh ahli desain dan ahli materi. Uji coba dilakukan dengan uji coba individu, uji coba kelompok kecil, dan uji coba lapangan, serta uji keefektifan model pembelajaran dengan membandingkan hasil kelompok eksperimen dengan kelompok kontrol. Analisis menggunakan analisis deskriptif pada setiap tahap pengembangan dan dilanjutkan dengan analisis statistik uji-t untuk mengetahui keefektifan media Pembelajaran Berbasis Keterampilan Hijau Generik dalam Pembelajaran Berbasis Proyek dengan Menggunakan CAD dalam Keterampilan Menggambar Teknis untuk meningkatkan hasil belajar siswa. Hasil penelitian menunjukkan bahwa media Pembelajaran Keterampilan Hijau Generik dalam Pembelajaran Berbasis Proyek dengan Menggunakan CAD dapat dinyatakan layak untuk diterapkan dan unggul ditinjau dari aspek pembelajaran, materi, dan media; media Pembelajaran Keterampilan Hijau Generik dalam Pembelajaran Berbasis Proyek dengan Menggunakan CAD efektif untuk meningkatkan hasil belajar siswa pada Keterampilan Menggambar Teknik berbantuan CAD.
\end{abstract}

Kata Kunci: media pembelajaran, generic green skill, project based learning, gambar teknik, CAD

Abstract: This study aims to: (1) produce generic green skill based learning media in project based learning in CAD-assisted engineering drawing courses, (2) Determine the effectiveness of generic green skill based learning media in project based learning in engineering drawing courses. CAD-assisted. This study uses the Research and Development method proposed by the Borg \& Gall model. The research subjects were students of the Department of Mechanical Engineering Education, State University of Medan, who were reviewed by design experts and material experts. The trials were carried out by individual trials, small group trials, and field trials, as well as testing the effectiveness of the learning model by comparing the results of the experimental group with the control group. The analysis uses descriptive analysis at each stage of development and is followed by t-test statistical analysis to determine the effectiveness of Generic Green Skills-Based Learning media in Project-Based Learning by Using CAD in Technical Drawing Skills to improve student learning outcomes. The results showed that the Generic Green Skills Learning media in Project-Based Learning Using CAD can be declared feasible and superior in terms of the aspects of learning, material, and media; Learning media for Generic Green Skills in Project-Based Learning using CAD is effective to improve student learning outcomes on CAD-assisted Technical Drawing Skills.

Keywords: learning media, generic green skills, project based learning, engineering drawings, CAD

\section{PENDAHULUAN}

Gambar teknik merupakan suatu cara untuk menyatakan maksud, pokok-pokok pikiran atau gagasan dari seseorang perencana teknik (juru gambar) kepada operator permesinan atau konsumen yang memerlukan informasi di bidang teknik. Informasi-informasi tersebut harus lengkap, tepat, dan jelas, agar maksud, ide atau gagasan yang disampaikan dapat dibaca dan dipahami oleh pembaca gambar. Pembaca gambar harus dapat membaca dan memahami gambar teknik secara utuh dan menyeluruh tentang aturan dan ketentuan gambar teknik mesin. Ada bermacam-macam aturan dan ketentuan gambar teknik yang ada, salah satunya tentang gambar proyeksi dan cara penyajiannya. Auto CAD (Computer Aided Design) atau merancang berbantukan komputer adalah program aplikasi komputer yang sangat membantu dalam penggambaran di bidang rekayasa dan keteknikan sebagai bagian dalam teknologi yang diterapkan dalam gambar teknik. Kerangka kerja yang dibutuhkan bagi 
dosen adalah pemahaman keefektivifan integrasi pembelajaran.

Mahasiswa yang memilih Program

Studi Pendidikan Teknik Mesin berasal dari latar belakang yang berbeda-beda yaitu berasal dari latar belakang Sekolah Menengah Atas atau Madrasah Aliyah dan Sekolah Menengah Kejuruan. Observasi yang telah dilakukan ditemukan bahwa dibutuhkan media pembelajaran yang dapat digunakan untuk belajar mandiri di rumah dan membantu mahasiswa dalam memahami materi dan membantu mahasiswa dalam pengerjaan tugas menggambar teknik berbantuan CAD.

Gambar merupakan sarana tepat untuk menyampaikan ide atau gagasan seseorang kepada yang lain, Sato (2012: 1) menyatakan "penerusan informasi adalah fungsi yang penting untuk bahasa ataupun gambar. Gambar diharapkan mencakup keteranganketerangan secara tepat dan obyektif. Informasi yang didapat di dalamnya berupa visual gambar, simbol, lambang dan standar gambar. Informasi tersebut merupakan gagasan atau ide, konsep abstrak yang kemudian diwujudkan dengan gambar". Menggambar Teknik memiliki fungsi sebagai media penyampaian informasi yang komunikatif karena gambar dapat di mengerti, terukur (memiliki skala), akurat (presisi tepat teknis), efektif (tepat dalam penggunaannya), serta estetik (keindahannya). Tetapi gambar teknik tidak akan menimbulkan tafsiran yang berbeda bagi orang yang melihatnya. Oleh karena itu, perlu ada tanda-tanda/patokan tertentu sebagai suatu perjanjian bersama. Patokan-patokan tersebut biasanya terdapat dalam suatu normalisasi atau International Organization for Standardization (ISO).

Keterampilan hijau (generic green skill) pada pendidikan vokasional saat ini menjadi fokus dalam mengembangkan kemampuan siswa kejuruan. Dunia kerja sangat membutuhkan keterampilan yang berorientasi pada pekerjaan hijau atau green skill. Kompetensi mahasiswa vokasional bukan hanya dinilai pada keberhasilan akademis saja namun dinilai dari keterampilan hijau yang dikuasai seperti leadership skill, management skill dan communication skill.

Ana, Subekti, S, Hammidah, S. (2015), dalam penelitian menunjukan bahwa model pembelajaran berbasis proyek dengan pendekatan produksi berdasarkan penilaian ahli dapat mengembangkan keterampilan hijau generik siswa Generic Green Skills di toko kue karena lebih menekankan pada pengembangan kemampuan manajemen proyek, kemampuan kolaborasi, kreativitas dan kemampuan pemecahan masalah.

Efektivitas pembelajaran berbasis proyek terbukti didukung oleh penelitian. Itu menunjukkan bahwa pembelajaran berbasis proyek dapat meningkatkan berbagai kompetensi seperti prestasi akademik, tingkat pemikiran tinggi, keterampilan berpikir kritis yang lebih baik, kemampuan pemecahan masalah, kreativitas, kemandirian, kemampuan melihat situasi dari perspektif yang lebih baik, pemahaman pembelajaran yang lebih dalam. materi, sikap yang lebih positif terhadap studi, hubungan yang lebih positif dan mendukung di antara teman sebaya, fleksibilitas dalam komunikasi, dan motivasi belajar (Ana, Luthfiyah N. (2012); Ana. (2008); Felder, R.M. \& Brent, R. (1996); Jaques, D.(2000); Thomas, J.W. (2000); Sharan, Y (1998). Pembelajaran berbasis proyek juga merupakan salah satu model yang mendukung penggunaan student centered learning (SCL), yang sekarang menjadi tantangan untuk implementasi proses pembelajaran di perguruan tinggi.

\section{Menggambar Teknik Berbantuan CAD}

Mata kuliah menggambar teknik berbantuan CAD merupakan mata kuliah yang berisi dasar-dasar dari menggambar teknik yang harus dikuasai oleh mahasiswa pendidikan teknik mesin, yang diberikan pada semester satu. Salah satu tujuan pembelajaran yang dicapai yaitu mampu memahami, menerapkan gambar dan lebih mengembangkan hasil karya gambarnya sesuai konstruksi kaidah-kaidah gambar teknik yang benar sesuai standar ISO. Dimana salah satu kompetensi dasarnya adalah mahasiswa mampu menggambar proyeksi. Materi yang disajikan pada mata kuliah menggambar teknik menggambar proyeksi adalah: (a) pengertian proyeksi, (b) proyeksi titik, (c) proyeksi garis, (d) proyeksi bidang, (e) proyeksi benda. Materi disajikan secara manuak dan dilanjutkan berbantuan CAD.

Gambar merupakan suatu alat untuk menyatakan maksud, pokok-pokok pikiran atau gagasan dari seseorang perencana teknik (juru gambar) kepada operator permesinan atau konsumen yang memerlukan informasi teknik (Emrizal, 2006: 1). Informasi-informasi tersebut harus lengkap, tepat, dan jelas, agar maksud, ide atau gagasan yang disampaikan dapat dibaca dan dipahami oleh pembaca gambar. 
Pandangan dalam gambar teknik mesin sebagian besar divisualisaikan dengan menggunakan gambar proyeksi lurus. Ada dua cara untuk menggambar proyeksi lurus, yaitu proyeksi sistem Amerika (Third Angle Pojection) dan proyeksi sistem Eropa (First Angle Projection) (Khumaedi, 2008: 23)

Standar Gambar Teknik ISO (International Organization for Standardization). Standar gambar teknik yang diterbitkan oleh ISO digunakan oleh mayoritas negaranegara Eropa Barat. Standar gambar teknik ISO sebenarnya merupakan adopsi standar gambar teknik yang diterbitkan oleh DIN Jerman (DIN 6). DIN 6 diterbitkan oleh Jerman pada tahun 1922. DIN 6 kemudian direvisi oleh Jerman pada tahun 1950 dan 1968. DIN 6 yang diadopsi ISO kemudian dinamakan dengan ISO 128. Pada saat baru diadopsi ISO 128 hanya terdiri atas 15 halaman. Seperti halnya standar-standar yang lain, ISO 128 terus dikembangkan sehingga ISO 128 pada tahun 2013 memiliki 14 bagian, di mana bagian pertama adalah tentang pendahuluan dan indeks (ISO 128-1:2003), dan 13 bagian lainnya yang terpisah, yang mengatur tata letak dan urutan gambar teknik (Y14 Policy Number One. 2007).

Standar Gambar Teknik yang diterbitkan oleh ISO dan ASME (ASME Y14.5, 2009) sudah cukup mengatur bagaimana suatu gambar teknik/mesin dibuat, sehingga memenuhi persyaratan yang dituntut terhadap suatu gambar teknik (Sato, 2012). Sebagai contoh, bagaimana beberapa jenis gambar sebagai berikut dapat dibuat dengan baik menggunakan standar ISO dan ASME tersebut; (1) Gambar Mesin berupa gambar susunan dan komponen; (2) Gambar Kerja (Working Drawing / Shop Drawing).

Penggunaan AutoCAD dalam menyampaikan materi gambar proyeksi dapat memberikan pemahaman yang lebih dan motivasi belajar karena di dalam AutoCAD berisi suatu tampilan audio visual atau gambar yang lebih menarik, lebih jelas dan dapat terlihat seperti gambar. Selain itu pada video CAD dijelaskan pembuatan benda kerja 3 dimensi, tampilan gambar pandangan bidang benda kerja dan gambar proyeksi sendiri. AutoCAD terdiri dari video gambar proyeksi sistem Amerika dan gambar proyeksi sistem Eropa. Setiap AutoCAD, gambar proyeksi yang dijelaskan dari menentukan pandangan gambar, penempatan gambar secara proporsional, pemberian garis gambar dan pemberian ukuran. Dalam pemberian pandangan gambar gambar, gambar yang dijelaskan adalah gambar pandangan depan, gambar pandangan samping kanan dan gambar pandangan atas. Hal tersebut sesuai dengan yang dikemukakan Khumaedi (2008: 3) bahwa agar dapat membuat pandangan gambar yang baik yaitu pandangan tidak berlebihan atau kurang. Seandainya objek yang digambar tidak komplek bisa menggunakan tiga pandangan.

\section{Keterampilan Hijau Generik (Generic Green Skills)}

Berbagai istilah digunakan untuk menggambarkan keterampilan generik. Sodemann (2008) menyebutnya sebagai keterampilan non-teknis, keterampilan kerja, keterampilan yang diperlukan dan kualifikasi utama, sementara Robles (2012) menamakannya soft skill. Yang lain menyebutnya kecerdasan emosi (Nicolaide, 2002 dalam Nik Safiah Nik Ismail, 2010). Keterampilan ini mungkin berbeda tergantung pada konteks dan situasi. Bagaimanapun, ini mengacu pada semua keterampilan selain keterampilan teknis yang dimiliki oleh karyawan. Menurut Lippman, Ryberg, Carney \& Moore (2015), soft skill adalah seperangkat keterampilan, sikap dan kualitas pribadi yang luas yang memungkinkan karyawan untuk mengelola lingkungan kerja mereka secara efektif, bekerja dengan nyaman dengan karyawan lain, melakukan tugas dengan baik dan fokus pada pencapaian tujuan yang ditargetkan. Mereka lebih lanjut menjelaskan bahwa keterampilan ini banyak digunakan dan melengkapi bidang pendidikan lainnya seperti teknis, kejuruan dan akademik.

Dalam konteks pekerjaan ramah lingkungan, Arasinah Kamis, Ridzwan Che Rus, Mohd Bekri Rahim, Faizal Amin Nur Yunus, Normah Zakaria \& Haryanti Mohd Affandi (2017) mendefinisikan keterampilan hijau sebagai keterampilan teknis, pengetahuan, nilai-nilai dan sikap yang dibutuhkan oleh tenaga kerja untuk mengembangkan dan mendukung keberlanjutan sosial, ekonomi, dan lingkungan. Definisi ini mencakup tiga bidang kehidupan karyawan.

Selain keterampilan hijau umum, beberapa sarjana menggabungkan keterampilan teknis dengan keterampilan hijau generik, yang menyebabkan munculnya Keterampilan Hijau, yang mungkin membingungkan banyak orang. 
Callan (2003) menetapkan bahwa ada kebingungan tentang berbagai istilah yang digunakan. Green skill adalah keterampilan yang menyatukan unsur-unsur pengetahuan,teknis dan keterampilannon-teknis, kemampuan dan sikap yang diperlukan untuk menghasilkan sumber daya manusia yang berkelanjutan (Mohd Shahril Mohd Hassan, Azman Hassan \& Ruslina Awang, 2016). Setelah itu, mereka mengklasifikasikan elemen keterampilan hijau menjadi keterampilan hijau 'lunak' dan keterampilan hijau 'keras'. Menurut mereka, keterampilan hijau lunak adalah keterampilan non-teknis, yang mencakup sikap dan kemampuan sedangkan keterampilan hijau keras adalah pengetahuan teknis dan keterampilan yang diperlukan untuk mencapai tujuan keberlanjutan. Secara keseluruhan ada 20 elemen keterampilan hijau 'lunak' dan 13 elemen keterampilan hijau 'keras' (Mohd Shahril Mohd Hassan et al., 2016). Karena motif utama keterampilan hijau umum adalah untuk melestarikan lingkungan, beberapa akademisi menyebutnya keterampilan ramah lingkungan (Asnawi dan Djatmiko, 2015).

Berkenaan dengan praktik-praktik inovatif di ruang kuliah seperti penggunaan komputer yang luas dan proyektor LCD, implementasi e-learning dan kesadaran akan penghematan listrik adalah beberapa contoh menanamkan keterampilan hijau generik dalam pengajaran dan pembelajaran. Bersamaan, siswa didorong untuk menggunakan smartphone. Untuk mencatat kehadiran siswa di ruang kuliah, kode QR digunakan secara luas. Ini menunjukkan bahwa kecerdikan siswa dalam penggunaan smartphone menunjukkan bahwa keterampilan digital adalah pelengkap lain untuk keterampilan hijau umum.

Temuan penelitian Hamid, Hassan, Nordin, Kmin, Atan, dan Suhairom (2019), menunjukkan bahwa keterampilan hijau generik adalah keterampilan tambahan yang melengkapi keterampilan generik yang ada dan fokus pada pelestarian dan menjaga kualitas lingkungan. Berkenaan dengan itu, menanamkan keterampilan hijau umum dalam kegiatan belajar mengajar dapat dilakukan melalui penggunaan Teknologi Informasi dan Komunikasi (TIK) yang melibatkan keterampilan digital, teknologi internet, dan konsumsi hemat listrik. Selanjutnya, studi tambahan keterampilan hijau generik diperlukan untuk berkontribusi pada pembangunan berkelanjutan.

\section{Pembelajaran Berbasis Proyek (Project Based Learning)}

Menurut Thomas (dalam Septiyani, 2015) menyatakan bahwa "pembelajaran berbasis proyek merupakan model pembelajaran yang memberikan kesempatan kepada guru untuk mengelola pembelajaran di kelas dengan melibatkan kerja proyek". Pembelajaran berbasis proyek ini lebih berpusat pada siswa dimana dalam pengelolaan pembelajaran di kelas akan dilibatkan suatu kegiatan proyek. Pembelajaran Project Based Learning merupakan model pembelajaran yang memberikan kesempatan kepada guru untuk mengelola pembelajaran di kelas dengan melibatkan kerja proyek. Kerja proyek memuat tugas-tugas yang kompleks berdasarkan kepada pertanyaan dan permasalahan yang sangat menantang dan menuntut peserta didik untuk merancang, memecahkan masalah, membuat keputusan, melakukan kegiatan investigasi, serta memberikan kesempatan kepada peserta didik untuk bekerja mandiri.

Menurut Yulianto (2017) model pembelajaran Project Based Learning pemberian tugas-tugas berdasarkan permasalahan kompleks yang diberikan pada siswa untuk melakukan investigasi permasalahan secara berkelompok. Memberikan kesempatan siswa lebih aktif belajar karena siswa didorong aktif dalam proses bertanya, menginvestigasi, menjelaskan, dan berinteraksi dengan permasalahan. Selanjutnya siswa diminta menghasilkan sebuah produk dari hasil investigasi dan dipresentasikan. Sejalan dengan pendapat sebelumnya, Sumarmi (2012) menyatakan bahwa Project Based Learning adalah proyek perseorangan atau kelompok yang dilaksanakan dalam jangka waktu tertentu guna menghasilkan sebuah produk, kemudian hasilnya ditampilkan atau dipersentasikan. Selain mengerjakan dan menggunakan berbagai macam sumber belajar perlu juga melakukan pendekatan belajar aktif atau berpusat pada siswa.

Keuntungan dari model pembelajaran Project Based Learning menurut Moursound, dkk (dalam Sumarmi, 2012) sebagai berikut. Pertama, meningkatkan motivasi. Peserta didik melaporkan bahwa belajar dalam proyek lebih fun dari pada komponen kurikulum yang lain. Laporan-laporan tertulis tentang proyek itu banyak yang menyampaikan bahwa peserta didik menjadi lebih tekun sampai kelewat batas. 
Kedua, meningkatkan kemampuan pemecahan masalah. Penelitian pada pengembangan keterampilan kognitif tingkat tinggi pada peserta didik menekankan perlunya keterlibatan peserta didik didalam tugas-tugas pemecahan masalah dan pembelajaran khususnya bagaimana menemukan dan memecahkan masalah. Ketiga, meningkatkan kolaborasi. Teori-teori kognitif yang baru dan kontrutivistis menegaskan bahwa belajar adalah fenomena sosial, dan peserta didik akan belajar lebih di lingkungan kolaboratif. Pembelajaran Berbasis Proyek merupakan pembelajaran kolaboratif berdasarkan teori konstruksionisme yang diungkapkan oleh Seymour Papert, teori ini menyatakan bahwa pembelajaran akan membentuk pengetahuan dibenak siswa secara bermakna dengan cara melibatkan siswa secara langsung dalam menciptakan suatu produk nyata, atau dengan kata lain pembelajaran diartikan sebagai proses berpikir dengan membuat sesuatu (Learning by making), Warsono (2013).

Project-based learning adalah suatu pendekatan pendidikan yang efektif yang berfokus pada kreatifitas berpikir, keterampilan berfikir, pemecahan masalah, dan interaksi antara siswa dengan teman sebaya (sejawat) mereka untuk menciptakan dan menggunakan pengetahuan baru. Rais (2010) menyampaikan Project based learning merupakan sebuah model pembelajaran yang sudah banyak dikembangkan di negara-negara maju seperti Amerika Serikat. Dalam bahasa Indonesia, Project Based Learning (PBL) bermakna sebagai pembelajaran berbasis proyek. Project Based Learning merupakan salah satu strategi pelatihan yang berorientasi pada CTL atau contextual teaching and learning process (Jones, Rasmussen dan Moffit, 1997).

Menurut Abidin (2016) Model

Pembelajaran Berbasis Proyek (Project Based Learning) adalah model pembelajaran secara langsung melibatkan siswa dalam proses pembelajaran melalui kegiatan penelitian untuk mengerjakan dan menyelesaikan suatu proyek pembelajaran tertentu. Sedangkan menurut (Mahendra: 2016) adalah model pembelajaran yang menggunakan proyek atau kegiatan sebagai media yang melibatkan peserta didik dalam mentransfer pengetahuan dan keterampilan melalui proses penemuan dengan serangkaian pertanyaan yang tersusun dalam tugas atau proyek. Dengan project based learning Siswa tidak hanya didorong untuk menyelesaikan langkah-langkah berdasarkan proyek kelas yang terkait dengan kepentingan pribadi mereka dan kebutuhan, tetapi juga untuk mengembangkan kemampuan berpikir kritis dan menggunakan pengetahuan konten (Kapp, 2009; Tamin \& Grant, 2013). Sejalan dengan hal tersebut bahwa pembelajaran berbasis proyek yang di integrasikan dalam pembelajaran bahasa dapat meningkatkan komunikasi komunikatif (Vaca \& Gómez: 2017). Bie (2012), dalam pembelajaran berbasis proyek, siswa akan melalui proses panjang dalam penyelidikan, menanggapi pertanyaan dari masalah yang kompleks, atau tantangan, melatih keterampilan yang dituntut di abad 21 .

Menelisik lebih dalam tentang PBL Roessingh dan Chambers (2011) mengemukakan bahwa elemen penting dalam desain proyek yaitu, (1) gambaran proyek dengan rasionalisasinya, (2) seperangkat tujuan pembelajaran yang jelas dan konsepkonsep kunci, (3) daftar bahan dan sumber daya, (4) memungkinkan seperangkat tugas, dan (5) kriteria penilaian dan rubrik. Menurut Rais (dalam Laraga, 2016) bahwa terdapat kelebihan dan kekurangan pada pembelajaran berbasis proyek. Adapun kelebihan dari pembelajaran berbasis proyek yaitu: (1) dapat meningkatkan motivasi; (2) meningkatkan kemampuan pemecahan masalah; 3) meningkatkan kolaborasi atau kerja kelompok; dan (4) meningkatkan keterampilan mengelola sumber. Sedangkan kelemahan dari model ini yaitu: (1) kebanyakan permasalahan "dunia nyata" yang tidak terpisahkan dengan masalah kedisplinan, untuk itu disarankan mengajarkan dengan cara melatih dan memfasilitasi peserta didik dalam menghadapi masalah; (2) memerlukan banyak waktu yang harus diselesaikan untuk menyelesaikan masalah; (3) membutuhkan biaya yang cukup banyak; (4) banyak instruktur yang merasa nyaman dengan kelas tradisional, dimana instruktur memegang peran utama di kelas; dan (5) banyak yang harus disediakan.

Konsep dasar model pembelajaran berbasis proyek adalah pentingnya memperlengkapi siswa dengan generic green skill umum. Berdasarkan tinjauan literatur, pengembangan model pembelajaran berbasis proyek patisserie mengacu pada model produksi Oakey, J. (1998); Sharan (1998); dan Han, S \& Bhattacharya, K. (2008).

Berdasarkan latar belakang masalah, maka penelitian ini dapat dirumuskan sebagai berikut: (1) Bagaimanakah mengembangkan 
media pembelajaran generic green skill based learning pada project based learning pada keahlian menggambar teknik berbantuan $\mathrm{CAD}$; (2) Apakah media pembelajaran generic green skill based learning pada project based learning layak digunakan pada menggambar teknik berbantuan CAD; dan (3) Apakah bahan ajar pembelajaran berbasis generic green skill in project based learning efektif dapat meningkatkan hasil belajar mahasiswa pada menggambar teknik berbantuan CAD.

\section{METODE}

Penelitian ini merupakan penelitian pengembangan (R\&D), yang dikembangkan menggunakan model ASSURE. Model ini terdiri atas 6 (enam) langkah yakni: (1) Analayze Learner, (2) State Objective, (3) Select Methods Media and Material, (4) Utilize Media and Materials, (5) Require Learner Participation, (6) Evaluate and Revise. Pemilihan model assure ini didasari bahwa model ini dikembangkan berdasarkan orientasi pada kelas. Menurut Heinich, Molenda, Russel, \& Smaldino, (2002). Dalam pengembangan media pembelajaran generic green skill based learning pada project based learning ini, rancangan pengembangan disesuaikan dengan model yang digunakan, adapun rancangan sebagai berikut.

1. Menganalisis kebutuhan belajar siswa dengan melihat karakteristik mahasiswa (Analayze Learner)

2. Menetapkan tujuan pembelajaran sebagai pedoman dan panduan kegiatan siswa (State Objective)

3. Menyusun metode bahan ajar yang sesuai dengan karakteristik peserta didik, dengan membuat bahan ajar baru serta melaksanakan uji ahli dan uji perseorangan pada bahan ajar yang telah dikembangkan.

4. Menggunakan/menerapkan bahan ajar yang telah disusun kepada peserta didik dalam proses pembelajaran (Utilize Media and Materials)

5. Melakukan uji kelompok serta meminta tanggapan tentang bahan ajar yang telah diterapkan (Require Learner Participation)

6. Melakukan evaluasi dengan melihat efektifitas penggunaan bahan ajar yang telah digunakan sekaligus merefleksi hasil dari evaluasi guna meningkatkan kualitas bahan ajar.

Penelitian ini dilakukan Jurusan Pendidikan Teknik Mesin, Fakultas Teknik,
Unimed Tahun Akademik 2019/2020, pada semester 1 matakuliah Menggambar Teknik Berbantuan CAD. Dengan merancang bahan ajar project based learning pada mata kuliah penulisan karya ilmiah. Subyek penelitian ini mahasiswa yang menempuh mata kuliah Menggambar Teknik Berbantuan CAD.

Data mengenai kualitas bahan ajar dilihat dari aspek desain, bahasa dan konten dianalisis secara deskriptif, untuk mengolah data hasil review ahli desain, bahasa, konten dan uji perseorangan. Teknik analisis data ini dilakukan dengan mengelompokan informasi dari data kualitatif yang berupa masukan, tanggapan, kritik, dan saran perbaikan yang terdapat pada angket. Hasil analisis ini kemudian digunakan untuk merevisi produk yang dikembangkan. Data mengenai uji kelompok dan tanggapan bahan ajar dengan memberikan kuisioner sesuai model assure. Dengan memberikan penilaian skala likert. Data mengenai efektifitas penggunaan bahan ajar dianalisis dengan statistik deskriptif.

Penelitian dilakukan di Program Studi Pendidikan Teknik Mesin UNIMED pada matakuliah menggambar teknik berbantuan CAD di semester 1 (Ganjil). Baik uji coba perorangan, ujicoba kelompok kecil, dan ujicoba utama dilakukan di Unimed. Pada tahap pengembangan media pembelajaran generic green skill based learning pada project based learning, penentuan sasaran dalam hal ini adalah dosen, pakar pembelajaran, ahli bidang studi, dan mahasiswa yang menilai media pembelajaran generic green skill based learning pada project based learning yang telah dikembangkan berdasarkan kriteria, sebagai berikut: (1) evaluasi pakar pembelajaran (expert judgement) ditentukan berdasarkan kepakaran yang dimilikinya, (2) evaluator yang melaksanakan evaluasi ditentukan berdasarkan pada kemampuan dosen dengan klasifikasi ahli bidang studi gambar teknik mesin dan CAD.

Teknik analisis data yang digunakan dalam penelitian ini yaitu teknik analisis deskriptif kuantitatif. Angket akan dibagi ke dalam 5 jenis pernyataan kemudian dikonveksikan ke dalam bentuk angka sebagai berikut.

Tabel 1. Pedoman Pemberian Skor

\begin{tabular}{|l|c|}
\hline \multicolumn{1}{|c|}{ Keterangan } & Skor \\
\hline SS (Sangat Setuju) & 5 \\
\hline S (Setuju) & 4 \\
\hline
\end{tabular}




\begin{tabular}{|l|l|}
\hline R (Ragu-ragu) & 3 \\
\hline TS (Tidak Setuju) & 2 \\
\hline STS (Sangat Tidak Setuju) & 1 \\
\hline
\end{tabular}

Skor yang telah diperoleh kemudian dijumlah untuk memperoleh rata-ratanya. Rumus yang digunakan untuk mencari rata-rata skor sesuai dengan Sudjana (2005:66) sebagai berikut:

$\overline{\mathrm{x}}=\frac{\sum \mathrm{Xi}}{\mathrm{n}}$

Keterangan: $\begin{aligned} \mathrm{X} & =\text { skor rata-rata } \\ \sum_{\mathrm{n}} \mathrm{xi} & =\text { jumlah skor } \\ & =\text { jumlah soal }\end{aligned}$

Setelah skor rata-rata diperoleh, maka kemudian pemberian kategori secara kualitatif disesuaikan dengan rumus Widoyoko (2010: 238).

Tabel 2. Konversi Data Kuantitatif ke Data Kualitatif

\begin{tabular}{|c|c|c|c|}
\hline N & Rentang skor & $\begin{array}{c}\text { Rentang } \\
\text { skor }\end{array}$ & Kategori \\
\hline 1 & $\mathrm{X}>\mathrm{Mi}+1,8 \mathrm{SBi}$ & $X>4,2$ & $\begin{array}{c}\text { Sangat } \\
\text { Baik }\end{array}$ \\
\hline 2 & $\begin{array}{c}\mathrm{Mi}+0,6 \mathrm{Sbi}<\mathrm{X} \\
\leq \mathrm{Mi}+1,8 \mathrm{SBi}\end{array}$ & $\begin{array}{c}3,4<X \leq \\
4,2\end{array}$ & Baik \\
\hline 3 & $\begin{array}{c}\mathrm{Mi}-0,6 \mathrm{Sbi}<\mathrm{X} \\
\leq \mathrm{Mi}+0,6 \mathrm{SBi}\end{array}$ & $\begin{array}{c}2,6<X \leq \\
3,4\end{array}$ & Cukup \\
\hline 4 & $\begin{array}{c}\mathrm{Mi}-1,8 \mathrm{Sbi}<\mathrm{X} \\
\leq \mathrm{Mi}-0,6 \mathrm{SBi}\end{array}$ & $\begin{array}{c}1,8<X \leq \\
2,6\end{array}$ & Kurang \\
\hline 5 & $\mathrm{X} \leq \mathrm{Mi}-1,8 \mathrm{SBi}$ & $X \leq 1,8$ & $\begin{array}{l}\text { Sangat } \\
\text { Kurang }\end{array}$ \\
\hline
\end{tabular}

Keterangan:

$\mathrm{X}=$ skor aktual (skor yang dicapai)

$\mathrm{Mi} \quad=$ rerata ideal

$=(1 / 2)$ (skor tertinggi ideal + skor

terendah ideal)

SBi = simpangan baku ideal

$=(1 / 6)$ (skor tertinggi ideal - skor

terendah ideal)

Berdasarkan tabel 3 maka produk pengembangan media dapat dikategorikan sesuai dengan penilaian berikut.

Tabel 3. Kategorisasi Produk

\begin{tabular}{|l|l|c|l|}
\hline No & \multicolumn{1}{|c|}{ Interval Skor } & Nilai & Kategori \\
\hline 1. & $\mathrm{X}>4,2$ & A & Sangat baik \\
\hline 2. & $3,4<\mathrm{X} \leq 4,2$ & B & Baik \\
\hline 3. & $2,6<\mathrm{X} \leq 3,4$ & C & Cukup \\
\hline 4. & $1,8<\mathrm{X} \leq 2,6$ & D & Kurang \\
\hline 5. & $\mathrm{X} \leq 1,8$ & E & Sangat Kurang \\
\hline
\end{tabular}

Kriteria kelayakan produk mengacu pada pendapat Sukardjo seperti yang dikutip dari Miyarso (2009: 69-70) bahwa suatu produk yang dikembangkan dapat dikatakan sudah layak digunakan sebagai media pembelajaran apabila hasil penilaian dari ahli materi, ahli media, guru, dan siswa memperoleh nilai termasuk dalam kriteria baik.

\section{Analisis Keefektifan Produk}

Analisis data dalam menguji keefektifan produk menggunakan analisis statistik. Untuk menganalisis perbedaan nilai pretes dan posttes kedua kelas digunakan uji $\mathrm{t}$ sampel (one sample $t$ test). Analisis data dilakukan dengan menggunakan aplikasi SPSS dengan pertimbangan agar data yang diberikan lebih tajam dan akurat.

Sebelum melakukan uji t, data dipastikan bersifat homogen dan berdistribusi normal. Untuk menguji normalitas, data yang diperoleh sesuai dengan hasil uji Shapiro dan Liliefors dalam SPSS. Data dikatakan normal jika hasil statistik menunjukkan angka $>0,05$. Sedangkan untuk menguji homogenitas, data diambil berdasarkan metode Levene's Test. Jika nilai yang diperoleh $>0,05$ maka data dikatakan homogen.

Setelah diadakan uji normalitas dan homogenitas, maka nilai tes kedua kelas diuji dengan SPSS. Jika nilai signifikansi $<0,05$ berarti Ho ditolak (ada perbedaan yang signifikan antara nilai pretes dengan nilai postes) (Saragih, 2015:189).

Hasil yang telah diperolah dari uji $\mathrm{t}$ sampel kemudian digunakan untuk mengetahui peningkatan pemahaman mahasiswa dengan menggunakan teknik analisis data gain-test dalam menghitung nilai gain $(\mathrm{g})$.

$g=\frac{\text { skor postes }- \text { skor pretes }}{\text { skor ideal }- \text { skor pretes }}$

(Sumber: Herlanti, 2014:74)

Nilai gain yang telah diperoleh kemudian dikategorikan sesuai dengan penilaian pada tabel berikut (Jumiati, dkk., 2011:170) .

Tabel 4. Kriteria Nilai Gain

\begin{tabular}{|l|l|}
\hline \multicolumn{1}{|c|}{ Nilai $\mathrm{g}$} & \multicolumn{1}{c|}{ Kriteria } \\
\hline $\mathrm{g}>0,7$ & Tinggi \\
\hline $0,7 \geq \mathrm{g}>0,3$ & Sedang \\
\hline $\mathrm{g} \leq 0,3$ & Rendah \\
\hline
\end{tabular}


Peningkatan pemahaman siswa dikategorikan tinggi jika nilai gain yang diperoleh lebih dari 0,7, dikategorikan sedang jika nilai gain di antara 0,7 dan tidak sampai pada nilai 0,3 . Jika nilai yang diperoleh adalah 0,3 atau lebih sedikit, maka peningkatan pemahaman siswa dikategorikan rendah.

\section{HASIL PENELITIAN}

\section{Analisis Data Hasil Validasi Produk}

Hasil penilaian oleh ahli materi, ahli desain pembelajaran dan ahli rekayasa perangkat lunak pada setiap aspek penilaian secara keseluruhan ditentukan oleh skor ratarata pada kategorinya masing-masing. Hasil penilaian tersebut kemudian dianalisis untuk menentukan layak tidaknya, dikembangkan media pembelajaran interaktif berbasis computer pada matakuliah menggambar teknik. Adapun persentase rata-rata dari hasil penilaian ahli materi, ahli desain pembelajaran dan ahli rekayasa perangkat lunak akandiuraikan sebagai berikut.

\section{Analisis Data Hasil Evaluasi Ahli Materi}

Tabel 5. Persentase Rata-Rata hasil Penilaian Terhadap Media Pembelajaran Oleh Ahli Materi

\begin{tabular}{|c|c|c|c|}
\hline No & Kategorisasi & $\begin{array}{c}\text { Persentase } \\
\text { Rata-rata }\end{array}$ & Kriteria \\
\hline 1 & $\begin{array}{l}\text { Aspek materi } \\
\text { pembelajaran }\end{array}$ & $95,00 \%$ & SB \\
\hline 2 & $\begin{array}{l}\text { Aspek strategi } \\
\text { pembelajaran }\end{array}$ & $94,00 \%$ & SB \\
\hline 3 & $\begin{array}{l}\text { Aspek sistem } \\
\text { penyampaian } \\
\text { pembelajaran }\end{array}$ & $92,50 \%$ & SB \\
\hline \multicolumn{2}{|c|}{ Rata-rata } & $\mathbf{9 3 , 8 3 \%}$ & SB \\
\hline
\end{tabular}

Ahli materi menilai media pembelajaran interaktif matakuliah menggambar teknik berdasarkan tiga aspek yaitu kualitas materi pembelajaran, kualitas strategi pembelajaran dan kualitas sistem penyampaian pembelajaran yang menunjukkan persentase rata-rata penilaian masing-masing 95,00\% pada aspek kualitas materi pembelajaran, $94,00 \%$ pada aspek kualitas strategi pembelajaran, dan $92,50 \%$ pada aspek sistem penyampaian pembelajaran termasuk kategori sangat baik secara keseluruhan, yang berarti media pembelajaran interaktif pada mata kuliah Menggambar teknik dapat memenuhi tuntutan kebutuhan pembelajaran.
Hasil penilaian terhadap materi pembelajaran pada ketiga topik materi kuliah menggambar teknik yang dikembangkan, yaitu proyeksi untuk gambar kerja, proyeksi eropa, dan proyeksi eropa menunjukkan beberapa kesalahan kecil yang berupa kesalahan peletakan tombol navigasi pada halamanhalaman presentasi, bukan merupakan kesalahan konsep dan dapat diperbaiki melalui revisi. Media pembelajaran interaktif pada matakuliah menggambar teknik oleh ahli materi dinyatakan layak untuk uji coba lapangan dengan revisi pada bagian yang salah.

\section{Analisis Data Hasil Evaluasi Ahli Desain Pembelajaran}

Tabel 6. Persentase Rata-Rata Hasil Penilaian Terhadap Media Pembelajaran Oleh Ahli Desain Pembelajaran

\begin{tabular}{|c|c|c|c|}
\hline No & Kategorisasi & $\begin{array}{c}\text { Persentase } \\
\text { Rata-rata }\end{array}$ & Kriteria \\
\hline 1 & $\begin{array}{l}\text { Kualitas desain } \\
\text { pembelajaran }\end{array}$ & $87,50 \%$ & SB \\
\hline 2 & $\begin{array}{l}\text { Kualitas desain } \\
\text { informasi }\end{array}$ & $87,50 \%$ & SB \\
\hline 3 & $\begin{array}{l}\text { Kualitas desain } \\
\text { interaksi }\end{array}$ & $92,50 \%$ & $\mathrm{SB}$ \\
\hline 4 & $\begin{array}{l}\text { Kualitas Desain } \\
\text { Presentasi }\end{array}$ & $81,70 \%$ & SB \\
\hline \multicolumn{2}{|r|}{ Rata-rata } & $87,30 \%$ & SB \\
\hline
\end{tabular}

Penilaian ahli desain pembelajaran terhadap aspek kualitas desain pembelajaran menunjukkan persentase rata-rata $87,50 \%$ termasuk kategori sangat baik yang berarti penampilan fisik media pembelajaran interaktif mata kuliah Menggambar teknik fungsional bagi peningkatan motivasi belajar peserta didik. Penilaian ahli desain pembelajaran terhadap aspek kualitas desain informasi menunjukkan persentase rata-rata $87,50 \%$ termasuk kategori sangat baik, yang berarti informasi media pembelajaran interaktif berbasis komputer pada matakuliah menggambar teknik dapat memberikan kemudahan bagi mahasiswa untuk memperoleh informasi yang diinginkan.

Penilaian ahli desain pembelajaran terhadap aspek kualitas desain interaksi menunjukkan persentase rata-rata $92,50 \%$ termasuk kategori sangat baik yang berarti pengaturan isi pembelajaran memperhatikan aspek interaksi antara peserta mahasiswa dengan pembelajaran sehingga dapat tercipta suatu kondisi yang mampu memfasilitasi belajar. Sedangkan persentase rata-rata pada 
aspek desain presentasi adalah 81,70\% termasuk kategori sangat baik yang berarti presentasi dari media pembelajaran interaktif yang dikembangkan memiliki tampilan yang menarik sehingga mampu menimbulkan rasa ketertarikan mahasiswa untuk melakukan pembelajaran.

\section{Analisis Data Hasil Evaluasi Ahli Rekayasa Perangkat Lunak}

Tabel 7. Persentase Rata-Rata Hasil Penilaian Terhadap Media Pembelajaran Oleh Ahli Rekayasa Perangkat Lunak.

\begin{tabular}{|c|l|c|l|}
\hline No & \multicolumn{1}{|c|}{ Kategorisasi } & $\begin{array}{c}\text { Persentase } \\
\text { Rata-rata }\end{array}$ & $\begin{array}{c}\text { Kri } \\
\text { teria }\end{array}$ \\
\hline 1 & Pemprograman & $92,50 \%$ & SB \\
\hline 2 & $\begin{array}{l}\text { Kualitas teknis atau } \\
\text { tampilan }\end{array}$ & $95,70 \%$ & SB \\
\hline \multicolumn{2}{|c|}{ Rata-rata } & $\mathbf{9 4 , 1 0 \%}$ & SB \\
\hline
\end{tabular}

Penilaian ahli desain rekayasa perangkat lunak terhadap aspek pemprograman menunjukkan persentase rata-rata $92,50 \%$ termasuk kategori sangat baik yang berarti program prangkat lunak pada media pembelajaran interaktif berbasis komputer matakuliah menggambar teknik berfungsi dengan baik bagi mahasiswa dalam memberi kemudahan dalam mendapatkan informasi yang diinginkan. Penilaian ahli desain pembelajaran terhadap aspek kualitas teknis atau tampilan menunjukkan skor rata-rata $95,70 \%$ termasuk kategori sangat baik, yang berarti media pembelajaran interaktif berbasis komputer pada matakuliah menggambar teknik dapat memberikan motivasi dan mampu menciptakan kondisi yang mampu memfasilitasi proses pembelajaran bagi mahasiswa.

\section{Hasil Uji Coba Tahap IV Uji Coba Lapangan}

Uji coba lapangan juga dilakukan terhadap mahasiswa Fakultas Teknik Jurusan Pendidikan Teknik Mesin yang teridiri dari 58 mahasiswa dari dua kelas yaknik kelas A sebanyak 29 mahasiswa dan kelas B sebanyak 29 mahasiswa. Uji coba lapangan menghasilkan data-data yang nantinya akan mengukur kelayakan dari produk yang dikembangkan, serta untuk mengetahui bagaimana manfaat produk tersebut bagi pemakainya. Hasil evaluasi terhadap media pembelajaran pada aspek kualitas materi pembelajaran dapat dilihat pada tabel pada Tabel 7 .
Tabel 7 menunjukkan hasil tanggapan mahasiswa pada aspek kualitas materi pembelajaran untuk uji coba lapangan keseluruhannya dalam kriteria "Sangat Baik"

Tabel 8. Skor Penilaian Media Pembelajaran Interaktif Berbasis Komputer Menggambar Teknik Uji Coba Lapangan Pada Aspek Kualitas Materi Pembelajaran

\begin{tabular}{|c|c|c|c|c|c|c|c|c|}
\hline \multirow{2}{*}{$\mathrm{N}$} & \multirow{2}{*}{$\begin{array}{l}\text { Indikator } \\
\text { Penilaian }\end{array}$} & \multicolumn{5}{|c|}{ Skor } & \multirow{2}{*}{$\begin{array}{l}\text { Rata- } \\
\text { rata }\end{array}$} & \multirow{2}{*}{$\begin{array}{l}\text { Kri } \\
\text { teri } \\
\mathrm{a}\end{array}$} \\
\hline & & 1 & 2 & 3 & 4 & 5 & & \\
\hline 1 & $\begin{array}{l}\text { Kesesuaian } \\
\text { materi }\end{array}$ & & & & 6 & $\begin{array}{l}5 \\
2 \\
\end{array}$ & $\begin{array}{c}97,93 \\
\%\end{array}$ & SB \\
\hline 2 & $\begin{array}{l}\text { Kejelasan } \\
\text { petunjuk } \\
\text { belajar }\end{array}$ & & & & 3 & $\begin{array}{l}5 \\
5\end{array}$ & $\begin{array}{c}98,97 \\
\% \\
\end{array}$ & SB \\
\hline 3 & $\begin{array}{l}\text { Kemudahan } \\
\text { memahami } \\
\text { kalimat pada } \\
\text { teks }\end{array}$ & & & & $\begin{array}{l}1 \\
3\end{array}$ & $\begin{array}{l}4 \\
5\end{array}$ & $\begin{array}{c}95,52 \\
\%\end{array}$ & SB \\
\hline 4 & $\begin{array}{l}\text { Kemudahan } \\
\text { memahami } \\
\text { pembelajara } \\
\mathrm{n}\end{array}$ & & & & $\begin{array}{l}1 \\
0\end{array}$ & $\begin{array}{l}4 \\
8\end{array}$ & $\begin{array}{c}96,55 \\
\%\end{array}$ & SB \\
\hline 5 & $\begin{array}{l}\text { Ketepatan } \\
\text { urutan } \\
\text { penyajian }\end{array}$ & & & & 5 & $\begin{array}{l}5 \\
3\end{array}$ & $\begin{array}{c}98,28 \\
\% \\
\end{array}$ & SB \\
\hline 6 & $\begin{array}{l}\text { Kecukupan } \\
\text { latihan }\end{array}$ & & & & $\begin{array}{l}1 \\
3\end{array}$ & $\begin{array}{l}4 \\
5\end{array}$ & $\begin{array}{c}95,52 \\
\%\end{array}$ & SB \\
\hline 7 & $\begin{array}{l}\text { Kejelasan } \\
\text { umpan balik }\end{array}$ & & & & & $\begin{array}{l}5 \\
8 \\
\end{array}$ & $\begin{array}{c}100,0 \\
0 \%\end{array}$ & SB \\
\hline 8 & $\begin{array}{l}\text { Bantuan } \\
\text { belajar } \\
\text { dengan } \\
\text { program }\end{array}$ & & & & & $\begin{array}{l}5 \\
8\end{array}$ & $\begin{array}{c}100,0 \\
0 \%\end{array}$ & SB \\
\hline & & & & & & & $\begin{array}{c}97,84 \\
\% \\
\end{array}$ & SB \\
\hline
\end{tabular}

Hasil evaluasi terhadap media pembelajaran pada aspek kualitas teknis atau tampilan dapat dilihat pada tabel pada Tabel 8 . Tabel 8 menunjukkan hasil tanggapan mahasiswa pada aspek kualitas teknis atau tampilan untuk uji coba lapangan keseluruhannya dalam kriteria "Sangat Baik".

Tabel 9. Skor Penilaian Media Pembelajaran Interaktif Berbasis Komputer Pada Matakuliah Menggambar teknik Uji Coba Lapangan Pada Aspek Kualitas Teknis atau Tampilan

\begin{tabular}{|c|c|c|c|c|c|c|c|c|}
\hline \multirow[b]{2}{*}{$\begin{array}{l}\mathrm{N} \\
\mathrm{O}\end{array}$} & \multirow[b]{2}{*}{$\begin{array}{l}\text { Indikator } \\
\text { Penilaian }\end{array}$} & \multicolumn{5}{|c|}{ Skor } & \multirow[b]{2}{*}{$\begin{array}{l}\text { Rata- } \\
\text { rata }\end{array}$} & \multirow{2}{*}{$\begin{array}{l}\text { Kri } \\
\text { teri } \\
\text { a }\end{array}$} \\
\hline & & 1 & 2 & 3 & 4 & 5 & & \\
\hline 1 & Keindahan & & & & & 5 & 100,0 & SB \\
\hline
\end{tabular}




\begin{tabular}{|c|c|c|c|c|c|c|c|c|}
\hline \multirow[b]{2}{*}{$\begin{array}{l}\mathrm{N} \\
\mathrm{o}\end{array}$} & \multirow[b]{2}{*}{$\begin{array}{l}\text { Indikator } \\
\text { Penilaian }\end{array}$} & \multicolumn{5}{|c|}{ Skor } & \multirow[b]{2}{*}{$\begin{array}{l}\text { Rata- } \\
\text { rata }\end{array}$} & \multirow{2}{*}{$\begin{array}{l}\text { Kri } \\
\text { teri }\end{array}$} \\
\hline & & 1 & 2 & 3 & 4 & 5 & & \\
\hline & $\begin{array}{l}\text { tampilan } \\
\text { layar }\end{array}$ & & & & & 8 & $0 \%$ & \\
\hline 2 & $\begin{array}{l}\text { Keterbaca } \\
\text { an teks }\end{array}$ & & & & & $\begin{array}{l}5 \\
8\end{array}$ & $\begin{array}{c}100,0 \\
0 \%\end{array}$ & SB \\
\hline 3 & $\begin{array}{l}\text { Kualitas } \\
\text { gambar } \\
\text { dan } \\
\text { animasi }\end{array}$ & & & & 5 & $\begin{array}{l}5 \\
3\end{array}$ & $\begin{array}{c}98,28 \\
\%\end{array}$ & SB \\
\hline 4 & $\begin{array}{l}\text { Komposisi } \\
\text { warna }\end{array}$ & & & & $\begin{array}{l}1 \\
5 \\
\end{array}$ & $\begin{array}{l}4 \\
3 \\
\end{array}$ & $\begin{array}{c}94,83 \\
\% \\
\end{array}$ & SB \\
\hline 5 & Navigasi & & & & 9 & $\begin{array}{l}4 \\
9 \\
\end{array}$ & $\begin{array}{c}96,90 \\
\% \\
\end{array}$ & SB \\
\hline 6 & $\begin{array}{l}\text { Daya } \\
\text { dukung } \\
\text { musik }\end{array}$ & & & & 8 & $\begin{array}{l}5 \\
0\end{array}$ & $\begin{array}{c}97,24 \\
\% \\
\end{array}$ & SB \\
\hline 7 & Interaksi & & & & 2 & $\begin{array}{l}5 \\
6 \\
\end{array}$ & $\begin{array}{c}99,31 \\
\%\end{array}$ & SB \\
\hline & & & & & & & $\begin{array}{c}98,08 \\
\%\end{array}$ & SB \\
\hline
\end{tabular}

Hasil penilaian uji coba lapangan terhadap aspek kualitas materi pembelajaran pada media pembelajaran interaktif berbasis komputer pada matakuliah menggambar teknik dirangkum pada Tabel 9. Hasil tanggapan mahasiswa pada Tabel 9 menyatakan bahwa untuk aspek kualitas materi pembelajaran pada uji coba lapangan menunjukkan 58 orang $(100,00 \%)$ menyatakan "Sangat Baik".

Tabel 10. Tingkat Kecenderungan Penilaian Terhadap Aspek Kualitas Materi Pembelajaran Pada Uji Coba Lapangan

\begin{tabular}{|c|c|c|c|c|}
\hline No & $\begin{array}{l}\text { Kategori } \\
\text { sasi }\end{array}$ & $\begin{array}{c}\text { Rentang } \\
\text { Skor }\end{array}$ & $\begin{array}{c}\text { Fre } \\
\text { kuensi }\end{array}$ & $\begin{array}{c}\text { Persen } \\
\text { tase } \\
(\%)\end{array}$ \\
\hline 1 & Sangat baik & $\begin{array}{c}81 \% \leq \mathrm{X} \leq \\
100 \%\end{array}$ & 58 & $\begin{array}{l}100,0 \\
0 \% \%\end{array}$ \\
\hline 2 & Baik & $\begin{array}{c}61 \% \leq X \leq \\
80 \%\end{array}$ & 0 & $\begin{array}{c}0,00 \\
\%\end{array}$ \\
\hline 3 & Sedang & $\begin{array}{c}41 \% \leq X \leq \\
60 \%\end{array}$ & 0 & $\begin{array}{c}0,00 \\
\%\end{array}$ \\
\hline 4 & $\begin{array}{l}\text { Kurang } \\
\text { baik }\end{array}$ & $\begin{array}{c}21 \% \leq \mathrm{X} \leq \\
40 \%\end{array}$ & 0 & $\begin{array}{c}0,00 \\
\%\end{array}$ \\
\hline 5 & $\begin{array}{l}\text { Sangat } \\
\text { kurang }\end{array}$ & $\begin{array}{c}0 \% \leq X \leq \\
20 \%\end{array}$ & 0 & $\begin{array}{c}0,00 \\
\%\end{array}$ \\
\hline \multicolumn{3}{|c|}{ Jumlah } & 58 & $\begin{array}{c}100,00 \\
\%\end{array}$ \\
\hline
\end{tabular}

Hasil tanggapan mahasiswa pada uji coba lapangan pada aspek kualitas teknis atau tampilan menunjukkan bahwa 58 orang $(100 \%)$ menyatakan "Sangat Baik" tampak pada Tabel 10.
Tabel 11. Tingkat Kecenderungan Penilaian Terhadap Aspek Kualitas Media Pembelajaran Pada Uji Coba Lapangan

\begin{tabular}{|c|c|c|c|c|}
\hline $\begin{array}{l}\mathrm{N} \\
\mathrm{O}\end{array}$ & $\begin{array}{l}\text { Kategori } \\
\text { sasi }\end{array}$ & $\begin{array}{c}\text { Rentang } \\
\text { Skor }\end{array}$ & $\begin{array}{c}\text { Fre } \\
\text { kuen } \\
\text { si }\end{array}$ & $\begin{array}{c}\text { Persen } \\
\text { tase }\end{array}$ \\
\hline 1 & Sangat baik & $\begin{array}{c}81 \% \leq X \leq \\
100 \%\end{array}$ & 58 & $\begin{array}{c}100,00 \\
\%\end{array}$ \\
\hline 2 & Baik & $\begin{array}{c}61 \% \leq \mathrm{X} \leq \\
80 \%\end{array}$ & 0 & $0,00 \%$ \\
\hline 3 & Sedang & $\begin{array}{c}41 \% \leq X \leq \\
60 \%\end{array}$ & 0 & $0,00 \%$ \\
\hline 4 & $\begin{array}{l}\text { Kurang } \\
\text { baik }\end{array}$ & $\begin{array}{c}21 \% \leq X \leq \\
40 \%\end{array}$ & 0 & $0,00 \%$ \\
\hline 5 & $\begin{array}{l}\text { Sangat } \\
\text { kurang }\end{array}$ & $\begin{array}{c}0 \% \leq X \leq \\
20 \%\end{array}$ & 0 & $0,00 \%$ \\
\hline \multicolumn{3}{|c|}{ Jumlah } & 58 & $\begin{array}{c}100,00 \\
\%\end{array}$ \\
\hline
\end{tabular}

Berdasarkan hasil analisis data statistik deskriptif pada Tabel 11, terlihat bahwa ratarata hasil posttest prestasi belajar pada kelompok yang pembelajarannya menggunakan Pengembangan media pembelajaran generic green skill based learning pada project based learning Pada Keahlian Menggambar Teknik Berbantuan CAD.

Penelitian pada tahap selanjutnya yaitu tahap II, diharapkan akan dapat menghasilkan dan mengembangkan media pembelajaran generic green skill based learning pada project based learning Pada Keahlian Menggambar Teknik Berbantuan CAD. media pembelajaran generic green skill based learning pada project based learning Pada Keahlian Menggambar Teknik Berbantuan CAD mampu memberikan pola strategi pembelajaran yang berbeda sesuai dengan tingkat dan perkembangan kognitif mahasiswa, serta penggunaan teknologi yang menyertai dalam proses pembelajaran berlangsung. Kemampuan ditekankan pada kemampuan tingkat tinggi, yaitu pada C4 sampai dengan C6 sesuai dengan kemampuan kognitif mahasiswa dalam upaya meningkatkan penguasaan terhadap matakuliah menggambar teknik berbantuan CAD . Melalui serangkaian tahap pengembangan dan validasi ahli serta uji coba pada tahap II akan dapat menghasilkan model yang utuh dan yang dapat digunakan dalam pengembangan proses pembelajaran dengan baik pada mahasiswa.

Masing-masing ahli yang ditunjuk dalam melakukan review terhadap produk pengembangan pada pengembangan media pembelajaran generic green skill based learning 
pada project based learning Pada Keahlian Menggambar Teknik Berbantuan CAD maupun terhadap media pembelajaran adalah dosen tetap pendidikan teknik mesin Unimed.

Untuk mengetahui kualitas pembelajaran dengan menggunakan media pembelajaran generic green skill based learning pada project based learning Pada Keahlian Menggambar Teknik Berbantuan CAD dilakukan implementasi penerapan media pembelajaran generic green skill based learning pada project based learning Pada Keahlian Menggambar Teknik Berbantuan CAD. Tujuan penggunaan media pembelajaran generic green skill based learning pada project based learning Pada Keahlian Menggambar Teknik Berbantuan CAD pada matakuliah menggambar teknik untuk meningkatkan kualitas pembelajaran dan karakter mahasiswa yang dikembangkan, kompetensi dan materi pembelajaran yang telah ditemukan pada tahap pertama.

Hasil uji coba dan validasi dari ahli untuk selanjutnya dilakukan revisi pada masingmasing aspek dan komponen media pembelajaran generic green skill based learning pada project based learning Pada Keahlian Menggambar Teknik Berbantuan CAD untuk penyempurnaan model pembelajaran yang dikembangkan.

Hasil penilaian uji coba lapangan aspek kualitas materi pembelajaran pada media pembelajaran interaktif berbasis komputer pada mata kuliah menggambar teknik. Hasil tanggapan siswa menyatakan bahwa untuk aspek kualitas materi pembelajaran di lapangan uji coba itu menyatakan "Sangat Baik".

\section{Average results of learning to draw engineering with}

CAD

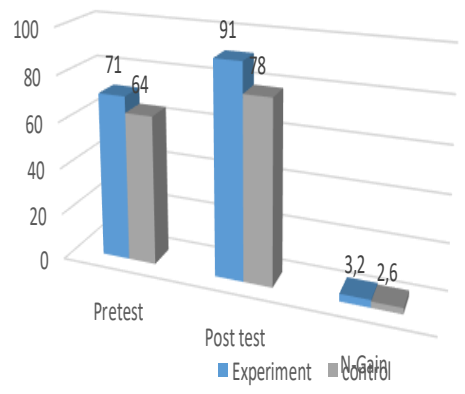

Gambar 1. Perbandingan nilai mean pretest, posttest dan n-gain media pembelajaran generic green skill based learning pada project based learning pada Keterampilan Menggambar Teknik berbantuan $\mathrm{CAD}$ dengan konvensional
Pembentukan komunitas belajar merupakan sarana pengembangan diri setiap dosen. Media Pembelajaran Berbasis Generic Green Skill dalam Project Based Learning pada CAD-Assisted Engineering Drawing Skills mengembangkan dan mengkonstruksikan pengetahuan dan wawasan untuk menjadi ahli yang lebih baik dari CAD-Assisted Engineering Drawing, diharapkan setiap mahasiswa siap untuk merubah pola pikir seperti yang telah dilakukan oleh penulis agar mendapatkan ideide berharga dalam proses pembelajaran.

Penerapan media pembelajaran generic green skill based learning pada project based learning pada Keterampilan Menggambar Teknik berbantuan CAD secara berkelanjutan akan membantu calon guru siswa mempercepat peningkatan profesionalnya. Indikator peningkatan melalui implementasi adalah perkembangan desain dan implementasi semester (RPS) yang selalu menuntut inovasi dan penilaian pembelajaran, yang memungkinkan siswa mengembangkan pemikiran kritis dan kreatif tentang pembelajaran dan pembelajaran, proses berbagi pengalaman berdasarkan observasi pembelajaran memberikan peluang bagi Dosen mengembangkan keterbukaan dan meningkatkan kompetensi sosialnya, serta proses refleksi secara berkelanjutan merupakan ajang bagi dosen untuk menumbuhkan kesadaran akan keterbatasannya.

Media pembelajaran generic green skill based learning pada project based learning pada Keterampilan Menggambar Teknik Berbantuan CAD adalah model pembelajaran alternatif yang diterapkan untuk meningkatkan kompetensi siswa dalam menggambar dan mengembangkan teknik mesin berbantuan CAD dan melalui kegiatan kolaboratif dan berkelanjutan serta selama pandemi Covid 19 . menggambar teknik bantuan CAD yang membutuhkan adaptasi terhadap pembelajaran dan kondisi yang selalu berubah.

Menggambar Teknik Berbantuan CAD merupakan matakuliah bidang pendidikan di jurusan pendidikan teknik mesin dan merupakan salah satu wujud dari pembentukan komunitas belajar yang harus di kuasai bagi pengajar/dosen dalam pelaksanaan pembelajaran menggambar teknik. Terbentuknya komunitas belajar merupakan sarana untuk pengembangan diri setiap dosen. Media pembelajaran generic green skill based learning pada project based learning Pada 
Keahlian Menggambar Teknik Berbantuan CAD akan meningkatkan rasa kebersamaan dan kolegialitas antara sesama mahasiswa dalam mempraktekkan dengan menggunakan karakter sebagai bagian penanaman dalam pembelajaran dan aspek konstruktivistik selalu ditekankan kepada mahasiswa agar dapat mengembangkan dan mengngonstruk pengetahuan dan wawasannya untuk lebih baik lagi.

Pelaksanaan pembelajaran dengan menerapkan media pembelajaran generic green skill based learning pada project based learning Pada Keahlian Menggambar Teknik Berbantuan CAD diharapkan setiap mahasiswa siap untuk mengubah mindset seperti yang sudah dilaksanakan oleh penulis dalam rangka untuk mendapat gagasan yang berharga dalam proses pembelajaran. Dosen atau Guru sebagai ujung tombak pendidikan diharapkan lebih bersifat terbuka, mau menerima perubahan apapun dalam dunia pendidikan dengan berupaya memperbaiki pembelajaran yang telah dilakukan dalam menggambar teknik berbantuan CAD. Media pembelajaran generic green skill based learning pada project based learning Pada Keahlian Menggambar Teknik Berbantuan CAD secara berkelanjutan akan membantu mahasiswa calon guru mempercepat peningkatan profesionalismenya. Indikatorindikator peningkatan melalui implementasi, adalah pengembangan rancangan dan pelaksanaan semester (RPS) yang selalu menuntut dilakukannya inovasi pembelajaran dan asesmen, yang memungkinkan mahasiswa untuk dapat mengembangkan pemikiran kritis dan kreatif tentang belajar dan pembelajaran, proses sharing pengalaman berbasis pengamatan pembelajaran memberi peluang bagi dosen untuk mengembangkan keterbukaan dan peningkatan kompetensi sosialnya, dan proses-proses refleksi secara berkelanjutan adalah suatu ajang bagi dosen untuk meningkatkan kesadaran akan keterbatasan dirinya.

\section{PENUTUP}

Hasil keseluruhan produk untuk uji validasi ahli yang meliputi ahli materi pelajaran, ahli desain pembelajaran, dan ahli desain grafis secara keseluruhan menunjukkan bahwa kualitas produk layak dan dapat digunakan dalam pembelajaran menggambar teknik berbantuan CAD.

Hasil uji coba individu, uji coba kelompok kecil, dan uji coba lapangan direvisi dan dianalisis untuk menemukan media pembelajaran berbasis green skill generik berbasis proyek menunjukkan bahwa model tersebut layak untuk digunakan dan diterapkan dalam pembelajaran teknik hambat berbantuan CAD.

Hasil penelitian ini menunjukkan bahwa penerapan media pembelajaran generic green skill based learning pada project based learning pada mata kuliah menggambar teknik berbantuan CAD memiliki hasil belajar yang lebih tinggi jika dibandingkan dengan model pembelajaran konvensional.

Keefektifan media pembelajaran generic green skill based learning pada project based learning pada pendidikan terhadap hasil belajar dengan menggunakan media yang digunakan dalam meningkatkan hasil belajar pada mata kuliah menggambar teknik berbantuan CAD yang telah dikembangkan untuk membuktikan tingkat penerapan dan keunggulannya

\section{DAFTAR PUSTAKA}

Ana, Luthfiyah N. (2012). Development Model of Patisserie Project-Based Learning. Journal Technical Education and Training UTHM Malaysia. JTET UTHM Malaysia 4 (2). ISSN 2229-8932

Ana, Subekti, S. \& Hamidah, S. (2015). The Patisserie Project Based Learning Model to Enhance Vocational Students' Generic Green Skills. Proceeding, The 3rd UPI International Conference on Technical and Vocational Education and Training (TVET). Published by Atlantis Press.

Ana. (2008). Project Based Learning: Alternative of Teaching and Learning Model for Pre-service Teacher Education in TVET, International Journal of Education 2 (2), May 2008.

ASME Y14.5 - (2009), ASME, 2009.

Asnawi R \& Djatmiko IW (2015). Tantangan Pendidikan Vokasi untuk Mempersiapkan Lapangan Kerja Hijau. Jurnal Internasional Pendidikan Teknis dan Kejuruan, XI (2): 154-160.

Callan VJ (2003). Keterampilan Generik: Memahami Pendidikan Kejuruan dan Pelatihan Sikap Guru dan Siswa. NCVER: SA, Australia.

Emrizal, M Z. (2006). Membaca dan Memahami Gambar Teknik Mesin. Yogyakarta: Yudistira 
Felder, R.M. \& Brent, R. (1996). Navigating the Bumpy Road to Student-Centered Instruction, College Teaching, 44, 43-47.

Hamid, Z., Hassan, Z., Nordin, S., Kamin, Y., Atan, N., \& Suhairom, N. (2019). Generic Green Skills in Teaching and Learning: Meaning and Implementation. Universal Journal of Educational Research 7(12A), 121-126, 2019. DOI: 10.13189/ujer.2019.071915

http://www.hrpub.org

Han, S \& Bhattacharya, K. (2008). Constructionism, Learning by Design, and Project Based Learning. Derived on 23 Juli 2014 from http://www.edutopia/projects.coe.uga.edu .htm.

Heinich, R., Molenda, M., Russel, J.D \& Smaldino, S.E. (2002). Instructional Media and Technologies for Learning. Edisi 7. Merril Prentice Hall. New Jersey-USA

Jaques, D.(2000). "Learning in Groups (3rd ed.)", London, Kogan Page.

Jones, Beau Fly, Rasmussen, Claudette M., \& Moffitt, Mary C. (1997) Real Life Problem Solving: A Collaborative Approach To Interdisciplinary Learning. Washington D.C.: American Psychological Association

Kapp, E. (2009). Improving student teamwork in a collaborative project-based course. College Teaching, 57(3), 139-143.

Khumaedi, M. (2008). Gambar Teknik. Buku Ajar. Semarang: Jurusan Teknik Mesin UNNES

Lippman LH, Ryberg R, Carney R \& Moore KA (2015). Keterampilan Lembut Utama Yang Menumbuhkan Kesuksesan Tenaga Kerja Muda: Menuju Konsensus Lintas Bidang. Koneksi Tenaga Kerja, Publikasi Tren Anak \# 2015-24.

Mahendra, I Wayan . (2016)."Project-Based Learning Bermuatan Etnomatematika dalam Pembelajar Matematika".Jurnal Pendidikan Indonesia. 6 (1) 106-114.

Mohd Shahril Mohd Hassan@ Abdul Ghani, Azman Hassan \& Ruslina Awang @ Faudzi (2016). Penerokaan Elemen Kemahiran Hijau. dalam $I^{\text {st }}$ Konferensi Nasionaldi TVET: Rapat Tantangan Inovasi dalamTVET.Fakultas Pendidikan
Teknik dan Kejuruan, Batu Pahat, Johor: Penerbit UTHM. 273-280.

Oakey, J. (1998). Project-Based and ProblemBased: The Same or Different?: http://pblmm.k12.us/PBLGuide/PBL\&P BL.html

Roessingh, H. \& Chambers, W. (2011). Projectbased learning and pedagogy in teacher preparation: staking out the theoretical Mid-Ground. International Journal of Teaching and Learning in Higher Education, 23 (1).

Sato, G.K. \& Sugiarto, N.H. (2012). Menggambar Mesin Menurut Standar ISO. Jakarta: PT Pradnya Paramita.

Septiyani, Putri Yunita. (2015). Penerapan Model Project Based Learning Pada Materi Hidrokarbon Dan Minyak Bumi Untuk Meningkatkan Hasil Belajar Dan Aktivitas Siswa Sma N 14 Semarang. Skripsi. Universitas Negeri Semarang. Semarang.

Sharan, Y. (1998)."Enriching the Group and Investigation in the Intercultural Classroom", European Journal of Intercultural Studies 9(2), 133-140

Sodemann K (2008). Keterampilan Lembut: Penting di Dunia Kerja dan Cara Melatih Mereka. Konferensi HRD Teknis Asia Pasifik dan Expo Karier '08, 6 -7, Kuching, Sarawak.

Sumarmi. (2012). Model-Model Pembelajaran Geografi. Malang: Aditya Media Publishing.

Thomas, J.W. (2000). A Review of Research on Project-Based Learning, California: The Autodesk Foundation, Derived on 5 November 2007 from: http://www.autodesk.com/foundation

Warsono dan Hariyanto. (2013). Pembelajaran Aktif: Teori dan Asesmen. Bandung: PT Remaja Rosdakarya Offset.

Y14 (2007). Policy Number One, Ground Rules for Placement of New or Revised ASME Data, Approved May 4.

Yulianto, Aris, A. Fatchan, I Komang Astina. (2017). Penerapan Model Pembelajaran Project Based Learning Berbasis Lesson Study untuk Menıngkatkan Keaktıfan Belajar Siswa. Jurnal Pendidikan: Teori, Penelitian, dan Pengembangan 2 (3),448-453. Tersedia Pada: http://journal.um.ac.id/index.php/jptpp/. 